\title{
Life cycle and development rate of Hemipyrellia ligurriens (Wiedemann) (Diptera: Calliphoridae) during monsoon season in South India: applications in estimation of postmortem interval
}

\author{
M. P. Reject Paul ${ }^{1}$ and C. F. Binoy ${ }^{2 *}$ \\ Research \& Post Graduate Department of Zoology, \\ St. Thomas' College (Autonomous), Thrissur-680001, Kerala,
}

Citation: Reject Paul, M. P. and C. F. Binoy. 2021. Life cycle and development rate of Hemipyrellia ligurriens (Wiedemann) (Diptera:Calliphoridae) during monsoon season in South India: applications in estimation of postmortem interval. J. Vet. Anim. Sci. 52 (3): $292-297$.

DOI: https://doi.org/10.51966/jvas.2021.52.3.292-297

Received: 27.05.2021

Accepted: 12.07.2021

Published: 30.09.2021

\section{Abstract}

Hemipyrellia ligurriens, considered as one of the forensically important blow fly species, has a wide distribution in many countries including India. To conduct forensic entomological investigations involving deaths of livestock, human beings and wild animals, standard life cycle data should be prepared for the local blow fly species under various weather conditions. Reliable forensic entomological data specific to geographic locations in India are not available presently to assist the post mortem interval assessment. In this study, life cycle and the rate of development of H.ligurriens was determined during monsoon season in Kerala, South India. Survival rate observed from egg to adult emergence was $44.68 \%$. Total duration of development of the species from oviposition till adult emergence was $462.57 \mathrm{~h}$. Growth curves based on the age, specific length parameter and time taken for development of each larval stage was constructed. This development model would be helpful for the medical, veterinary and law enforcement officials in forensic estimation of post mortem interval by analyzing the length parameters of larvae collected from decomposed dead bodies of humans, cadavers of wild animals and livestock.

Keywords: Hemipyrellia ligurriens, development stages, postmortem interval, veterinary forensics

The Hemipyrellia genus is represented by four species in the Oriental region. In India, it is represented by two species; H.pulchra and H.ligurriens (Senior-White et al.,1940;Nandi, 2004; Bharti,2011), the latter being reported on decomposing human cadavers in Malaysia (Rajagopal, 2013), Thailand (Moophayak et al., 2014)and other regions (Chen et al., 2004; Lee et al., 2004; Sukontason, 2007) and has significant forensic importance. These speciesare widely distributed

1. Research Scholar: Email Id : rpaulmp@stthomas.ac.in,Ph:9656370352

2. *Assistant Professor and corresponding author: email: binoycf@stthomas.ac.in, Ph: 8921645795

Copyright: () 2021 Reject Paul and Binoy. This is an open access article distributed under the terms of the Creative Commons Attribution 4.0 International License (http://creativecommons.org/licenses/by/4.0/), which permits unrestricted use, distribution, and reproduction in any medium, provided the original author and source are credited. 
in Taiwan, Philippines, Singapore, Papua New Guinea, China, Korea, Laos, SriLanka, Indonesia, Thailand, Australia and India(Tumrasvinet al., 1979;Kurahashi and Chowanadisai, 2001; Kurahashi, 1979).Though studies pertaining to the development of $H$.ligurriens has been done (Sinha and Nandi,2007; Sukontason et al., 2008;Sukontason et al., 2010; Bunchu et al., 2012), association of different larval instars with time since death is yet to be extensively investigated. Estimates of postmortem interval based on the known characteristics of the infesting fauna in the natural conditions of the specific geographical location are very important (Yang et al., 2015).Construction of growth curves based on the age specific length parameters of larvae versus time taken for development of each stage would be helpful for the estimation of the post mortem interval. In this study, the developmental rate of $H$.ligurriens was recorded during monsoon season to develop a model for the accurate estimation of postmortem interval in Kerala, South India.

\section{Materials and methods}

\section{Rearing of H.ligurriens}

The adult flies of $H$.ligurriens were reared in the outdoor open system rearing facility for blow flies in Kolangattukara, Choolissery, Thrissur district, Kerala, India (10 $\left.35^{\prime} 34.87^{\prime \prime} \mathrm{N}, 76^{\circ} 11^{\prime} 22.6^{\prime \prime} \mathrm{E}\right)$. Adult females of H.ligurriens were trapped and isolated in the rearing cabinet with decomposing pork (Sus scrofa) meat as bait. The adult flies were identified using morphological keys provided by Senior-White et al. (1940) with LEICA-S8APO stereomicroscope. Molecular diagnosis of the species was done by sequencing of cytochrome oxidase Subunit I (COI) gene which was done at Regional Facility for DNA Fingerprinting (RFDF), Rajiv Gandhi Centre for Biotechnology, Thiruvananthapuram, Kerala, India.

The insects were reared in the rearing cabinets (Size: $2 \mathrm{ft} \times 1 \mathrm{ft} \times 1 \mathrm{ft}$ ) positioned in the outdoor facility. Humidity, rainfall and temperature were monitored in the months of August and September, 2019. Temperature and humidity were monitor edusing hygrometer (HTC-1, Mode No:AP-IS11A056FBA, China). Rainfall data was collected from IMD-
Meteorological Centre, Thiruvananthapuram, Kerala. The adult insects were provided with 10 per cent $(\mathrm{w} / \mathrm{v})$ sugar solution and 1.5 per cent (v/v) multivitamin syrup solution and water as food and liquid sources. The decomposing pork served as reflex stimuli for the adult female to lay eggs and also served as a food source for the larvae. Wet vermiculite was kept as the bottom layer in the cabinet to assist migration of third instars for pupation.Few of the blow flies trapped were killed and pinned as dry specimens for morphological identification and few were preserved in 70per centethanol for molecular identification. Five numbers each of eggs, three different larvalinstars and pupae were randomly collected every six hours for further studies.

Observations were done regularly on hourly basis to detect the presence of eggs. Once the eggs were found, the bait with the eggs were transferred in to the larval rearing plastic jars. Wet vermiculite was laid at the bottom of the jar to maintain adequate humidity. The jar was covered with a wet cotton cloth to prevent the entry of other insect parasitoids. Fifty grams of fresh pork meat was put in to the jar as larval feed. This was continued until the instars reached the non-feeding stage and started pupal migration. Fresh pupae were collected and transferred to a new rearing jar with moist vermiculite at the bottom and it was kept inside the rearing cabinet for the emergence of the adult fly. Egg, different larval instars (Fig.1) and pupae were collected for studying their morphology and length/width parameters.

Morphological examination of $3^{\text {rd }}$ instar was done to study cephalopharyngeal skeleton andposteriorspiracleusing potassiumhydroxide enabled clearing. The alcohol preserved larvae werecut at the middle of second thoracic segment and at $11^{\text {th }}$ segment using a sharp blade under LEICA-S8APO stereomicroscope to study the cephalopharyngeal skeleton and posterior spiracle by digesting the anterior and posterior portions as per the methods by Sukontason et al. (2004). The cut anterior and posterior portions were treated with 10 percent $(w / v)$ of $\mathrm{KOH}$ solution in a watch glass for 48h. After rinsing the parts in four changes of distilled water, the specimen was treated in a mixture of 1 per cent glacial acetic acid and 35 
per cent ethyl alcohol in a watch glass for 30 min. Serial dehydration of the specimens was done using alcohol gradient $50 \%, 70 \%, 80 \%$ and $95 \%$ and absolute ethanol (99\%) by placing the specimen in each for 30 minutes. The specimens were treated in xylene for 60 and mounted on a microscopic slide with a coverslip using DPX mountant. The cephalopharyngeal skeleton and posterior spiracles were observed and photographed using LEICA-S8APO stereomicroscope with camera attachment.

\section{Life table study}

Life table studies were conducted to assess the percentage survival and mortality by recording the survival rate of different development stages.

\section{Assessment of developmental rate}

The phase from the time of oviposition till the emergence of adult fly from the pupae was considered for the study of developmental rate. The time taken by the eggs for hatching was noted. The freshly hatched larvae were transferred to the new larval rearing chamber and 50 grams of fresh pork meat was provided as food. Ten larvae were collected every six hours and boiled for two minutes at $96-99^{\circ} \mathrm{C}$ and preserved in $70 \%$ alcohol for the assessment of length and width. The time spent by the species in each life stage was recorded. Based on these observations growth curves were plotted. Effect of temperature, relative humidity and rainfall on larval development was also studied.

\section{Results and discussion}

The adults were identified as H.ligurriens based on the characteristics provided in standard literature Senior-White et al. (1940). The thorax had metallic green to copper colour, the parafrontalia, face and gena were silver grey, the third antennal segment dark brown and palpi had an orange colour. Numerous vertical hairs were present on the supra spiracular convexity. In males, frons was much narrowed. In females, the frons was about the same width as parafrontalia. Molecular identification of species done by sequencing $\mathrm{COI}$ gene and further analysis by
NCBI BLAST confirmed the species identity as $H$.ligurriens. The sequence was submitted in GenBank, NCBI and assigned with accession no.(GenBank Accession No: MN831480).

The study was conducted during August and September, 2019 and the average temperature and relative humidity in the same period were $27.01 \pm 1.15^{\circ} \mathrm{C}$ and $88.16 \pm 4.38$ $\%$ respectively. The average rain fall recorded during these months were $20.33 \pm 10.65$ $\mathrm{mm}$. Atotal of 94 eggs were reared in this study. Cephalopharyngeal skeleton of $3^{\text {rd }}$ instar larvae was complete having characteristic features like hooks, parastomal bar, anterior dorsal process, dorsal cornua ,ventral cornua.The posterior spiracle was seen with two welldeveloped posterior spiracular discs each with a completely separated peritreme, medially oriented 3 slits and very characteristic medially placed button(Fig 2.)

In the life table study conducted, 94 eggs laid during the 24 hour period were considered. Percentage survival and mortality of each development stage were assessed and the details are given in Table. 1. Of the 94 eggs reared, 78 (82.97\%) hatched and reached the first instar stage of which 63(67.02\%) became second instar, $57(60.63 \%)$ reached third instar stage of which $51(54.24 \%)$ became pupae. Fourty two emerged from pupae as adult flies. Total survival rate forH.ligurriens during monsoon season was $44.68 \%$.

The total duration taken by H. ligurriens for the development from the egg stage $(n=94)$ till the emergence of adult fly was $462.57 \mathrm{~h}$. Growth curve of different stages of H.ligurriens showing the relation between developmental time and length was constructed (Fig.3). Pupation time till emergence of adult fly was $164.85 \mathrm{~h}(\mathrm{n}=47)$. During larval development the species spent maximum time in third instar stage (215.28 $\pm 10.22 \mathrm{~h})$. The larvae attained maximum length $(7.67 \mathrm{~mm})$ and maximum width $(1.46 \mathrm{~mm})$ also during the third instar stage. It was interesting to note that larval length and larval width almost doubled in the second instar stage. The development rate (in hours) and mean length and width for the larval stages of H.ligurriens are provided in Table 2. 
Table 1. Survival rate of different life stages of $H$. ligurriens in Kerala, India

\begin{tabular}{|c|c|c|c|c|}
\hline SI. No & Stage & No. & Survival rate at each stage & Mortality rate at each stage \\
\hline 1 & Egg & 94 & $82.97 \%$ & $17.03 \%$ \\
\hline 2 & 1 st Instar & 78 & $67.02 \%$ & $32.98 \%$ \\
\hline 3 & $2^{\text {nd }}$ Instar & 63 & $60.63 \%$ & $39.37 \%$ \\
\hline 4 & $3^{\text {rd }}$ Instar & 57 & $54.24 \%$ & $45.76 \%$ \\
\hline 5 & Pupa & 51 & $44.68 \%$ & $55.32 \%$ \\
\hline 6 & Adult fly & 42 & - & - \\
\hline
\end{tabular}

Table 2. Length, width and duration of different life stages of $H$. ligurriens in natural conditions in Kerala, India

\begin{tabular}{|l|c|c|c|}
\hline \multicolumn{1}{|c|}{ Stage } & Length(Mean \pm SD) & Width(Mean \pm SD) & $\begin{array}{c}\text { Life span of each } \\
\text { stage(Mean } \pm \text { SD) }\end{array}$ \\
\hline Egg & $1.17 \pm 0.03 \mathrm{~mm}$ & $0.40 \pm 0.07 \mathrm{~mm}$ & $31.71 \pm 2.87 \mathrm{~h}$ \\
\hline 1st Instar & $2.65 \pm 0.07 \mathrm{~mm}$ & $0.52 \pm 0.04 \mathrm{~mm}$ & $18 \pm 4.43 \mathrm{~h}$ \\
\hline 2nd Instar & $5.27 \pm 0.43 \mathrm{~mm}$ & $0.98 \pm 0.05 \mathrm{~mm}$ & $32.71 \pm 4.96 \mathrm{~h}$ \\
\hline 3rd Instar & $7.67 \pm 0.33 \mathrm{~mm}$ & $1.46 \pm 0.26 \mathrm{~mm}$ & $215.28 \pm 10.22 \mathrm{~h}$ \\
\hline Pupa & $6.1 \pm 0.07 \mathrm{~mm}$ & $2.09 \pm 0.01 \mathrm{~mm}$ & $164.85 \pm 6.47 \mathrm{~h}$ \\
\hline
\end{tabular}

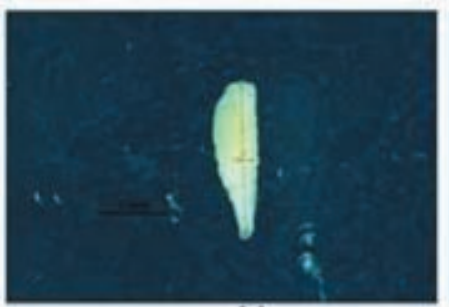

(a)

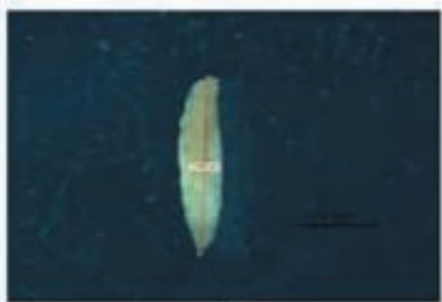

(b)

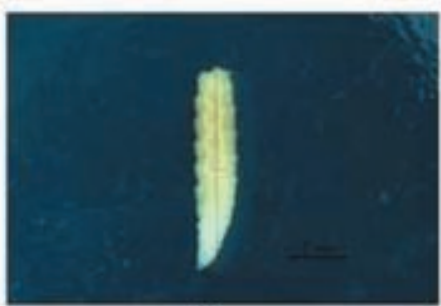

(c)

Fig.1. Different larval instars of H. ligurriens (a) First Instar (b) Second Instar (c) Third Instar

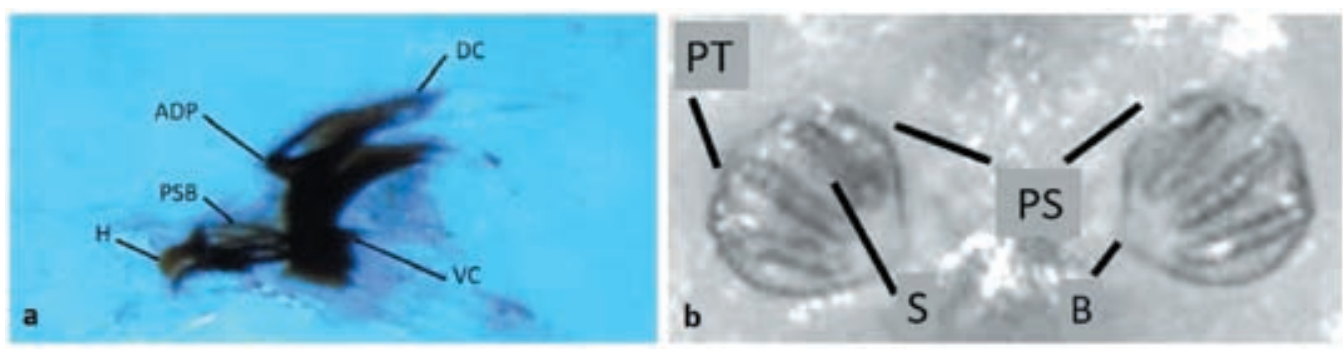

Fig 2.a.Cephalopharyngeal skeleton of $3^{\text {rd }}$ Instar showing hook(H), parastomal bar(PSB), anterior dorsal process(ADP), dorsal cornua(DC), ventral cornua(VC)b.Posterior spiracles(PS) of $3^{\text {rd }}$ Instar showing completely separated peritreme(PT), 3 diagonally placed slits(S), medially placed button(B)

The rate of development of $H$.ligurriens in this study (462.57 h) differed from the earlier reports from India (338.54h) by Sinhaand Nandi, (2007). The rate of development of the species in this study was slower by $191.17 \mathrm{~h}$ than that reported from Thailand by Bunchu et.al. (2012) and $181.27 \mathrm{~h}$ slower than that reported from China by Yang et.al. (2015). This might be due to the changes in the larval food(fish) and the influence of humidity, rainfall and temperature prevailing in these geographically different areas. The changes in the developmental rate of species also cautions that while performing the assessment of postmortem interval(PMI), the investigators should be very careful about the climatic conditions prevailing in the 


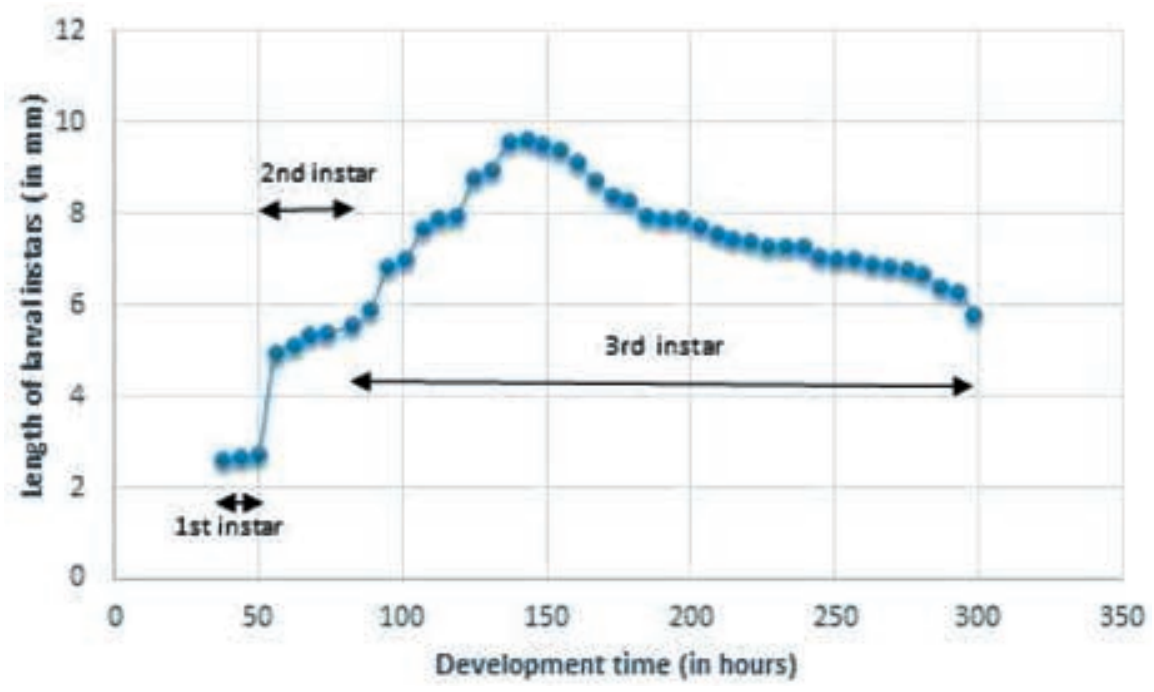

Fig.3 Relation between development time and larval length of H.ligurriens under natural conditions in Kerala, India

respective study area(Gallagher et al., 2010). This signifies the importance of generating location specific data of forensically important species for accurate assessment of PMI.

\section{Conclusion}

The current study on developmental rate of $H$. ligurriens would be useful in the forensic investigations involving decomposed dead bodies of humans, wild animals and livestock as this is the first report of this species from South India. Further studies are needed to find out the rate of development of $H$. ligurriens in other seasons so as to make a comprehensive database for this forensically significant blowfly species from Kerala, South India.

\section{Acknowledgement}

Wesincerely thankthe Regional Facility for DNA Fingerprinting (RFDF), Rajiv Gandhi Centre for Biotechnology, Thiruvananthapuram, Kerala for the DNA sequencing work. We also thank the Principal and Management of St. Thomas' College (Autonomous), Thrissur, Kerala, India for providing facility and support for conducting the present research work.

\section{Conflict of interest}

The authors declare that they have no conflict of interest.

\section{References}

Bharti, M. 2011.An updated checklist of blowflies (Diptera: Calliphoridae) from India. Halteres.3:34-37

Bunchu, N., Thaipakdee, C., Vitta, A., Sanit, S., Sukontason, K. and Sukontason, K.L.2012. Morphology and Developmental Rate of the Blow Fly, Hemipyrellia ligurriens (Diptera: Calliphoridae): Forensic Entomology Applications.J.Parasitol. Res.2012:https://doi.org/10.1155/ 2012/371243

Chen, W.Y., Hung,T.H.andShiao, S.F.2004. Molecular identification of forensically important blow fly species (Diptera: Calliphoridae) in Taiwan. J. Med. Entomol.41:47-57

Gallagher,M.B., Sandhu, S. and Kimsey, R.2010. Variation in developmental time for geographically distinct populations of the common green bottle fly, Lucilia sericata (Meigen).J. Forensic Sci. 55(2): 438-442

Kurahashi,H and Chowanadisai,L.2001. Blow flies (Insecta:Diptera:Calliphoridae)from Indochina. Species Diversity.6:185-242 
Kurahashi,H.,Benjaphong,N.andOmar,B.1997. Blowflies(Insecta:Diptera:Calliphoridae) of Malaysia and Singapore. Raffles Bull. Zool.5:1-88

Lee, H.L., Krishnasamy, M., Abdullah, A.G. and Jeffery, J.2004. Review of forensically important entomological specimens in the period of 1972-2002. Trop. Biomed.21:69-75

Moophayak, K., KlongKlaew, T., Sukontason, K., Kurahashi, H, Tomberlin, J.K. and Sukontason, K.L.2014. Species composition of carrion blowflies in northern Thailand: altitude appraisal, Rev. Inst. Med. Trop. Sao Paulo; 56:179 182

Nandi, B.C.2004.Checklist of Calliphoridae (Diptera) of India.Records of the Zoological Survey of India;Occasional paper No. 231. 1-47

Rajagopal, K.2013. Application of Forensic Entomology in Crime Scene Investigations in Malaysia, Ph.D. Thesis,University of Malaya, Kuala Lumpur.

Senior-White, R., Aubertin, D. and Smart, J.1940.The fauna of British India including remainder of the oriental region:DipteraVol VI family Calliphoridae. Taylor and Francis, London, United Kingdom.pp: 41-43.

Sinha, K.S. and Nandi,B.C.2007. Studies on life history of Hemipyrellia ligurriens (Weidemaan) (Diptera: Calliphoridae) in Sundarbans biosphere reserve West Bengal. India .Rec.Zool.Surv. India. 107(Part-1): 63-70

Sukontason, K.2007. Forensic entomology cases in Thailand: a review of cases from 2000 to 2006. Parasitol. Res.101:14171423
Sukontason, K., Methanitikorn, R., Sukontason, K. L., Piangjai, S. and Olson, J. K.2004. Clearing technique to examine the cephalopharyngeal skeletons of blow fly larvae.J.Vector Ecol.29(1):192-195.

Sukontason, K., Narongchai, P., Kanchai, C., Vichairat, K., Sribanditmongkol, P., Bhoopat, T., Kurahashi, H., Chockjamsai, M., Piangjai, S., Bunchu, N., Vongvivach, S., Samai, W., Chaiwong, T., Methanitikorn, R., Ngern-klun, R., Sripakdee, D., Boonsriwong, W., Siriwattanarungsee, S., Srimuangwong, C., Hanterdsith, B., Chaiwan, K., Srisuwan, C., Upakut, S., Moopayak, K., Vogtsberger, R.C., Olson, J.K., Sukontason, K., Sribanditmongkol, P. and Ngoen-klan.2010. Differentiation between Lucilia cuprina and Hemipyrellia ligurriens (Diptera: Calliphoridae) larvae for use in forensic entomology applications. Parasitol Res. 106: $641-646$

Sukontason, K., Sribanditmongkol,P., Chaiwong, T., Vogtsberger, R.andPiangjai, S. 2008. Morphology of immature stages of Hemipyrellia ligurriens (Weidemann) (Diptera:Calliphoridae) for use inforensic entomology applications. Parasitol.Res. 103: $877-887$

Tumrasvin,W.,Kurahashi,H. and Kano,R.1979. Studies on medically important flies in Thailand. VII. Report on 42 species of calliphorid flies, including the taxonomic keys Diptera: Calliphoridae). The Bulletin of the Tokyo Medical and Dental University.26(4): 243-272

Yang,Y.,Liu,Z.,Li,X., Li,K.,Yao,L. and Wan,L. 2015.Technical note: Development of Hemipyrellia ligurriens (Wiedemann) (Diptera: Calliphoridae) at constant temperatures: Applications in estimating postmortem interval.Forensic Sci. Int.253:48-54. 